\title{
A RECONSIDERATION OF THE MASS BALANCE OF A PORTION OF THE ROSS ICE SHELF, ANTARCTICA*
}

\author{
By Kenneth C. Jezek $\dagger$ and Charles R. Bentley
}

(Geophysical and Polar Research Center, University of Wisconsin-

Madison, 1215 West Dayton Street, Madison, Wisconsin 53706, U.S.A.)

\begin{abstract}
The identification of a small region of grounded ice in the north-western sector of the Ross Ice Shelf has forced a re-evaluation of the mass-balance calculations carried out by Thomas and Bentley (1978). Those authors concluded that the Ross Ice Shelf up-stream of Crary Ice Rise was thickening, but they did not take into account the effects on the velocity field of grounded ice (of which they were unaware), which is located near the input gate to their volume element. Reasonable estimates of the degree to which the ice velocity just up-stream of the grounded ice is diminished indicate that it is no longer possible to conclude that the ice shelf is thickening using Thomas and Bentley's original flow band. There fore, a new flow band was chosen which was grid east of Thomas and Bentley's band and unaffected by any nearby grounded areas. The mass balance in this flow band was found to be zero within experimental error; a difference exceeding about $0.2 \mathrm{~m} \mathrm{a}^{-1}$ in magnitude between the thickening and bottom freeze-on rates is unlikely.
\end{abstract}

RÉsumé. Une nouvelle estimation du bilan de masse d'une partie du Ross Ice Shelf, Antarctique. La découverte d'une petite région de glace reposant sur le sol dans le secteur nord-ouest du Ross Ice Shelf nous a contraints à réestimer les calculs du bilan de masse effectués par Thomas et Bentley (1978). Ces auteurs concluaient à un épaississement du Ross Ice Shelf à l'amont de la ride de glace Crary, Ice Rise, mais ils n'ont pas tenu compte des effets du champ de vitesse de la glace reposant sur le sol (ce dont ils n'avaient pas connaissance) qui est situé près de l'entrée de leur élément de volume. Des estimations raisonnables du degré de diminution de la vitesse juste à l'amont de la zone de glace reposant sur le sol indiquent qu'il n'est plus possible de

\section{INTRODUCTION}

The stability of a marine ice sheet probably depends, at least in part, on the state of its bounding ice shelves (Thomas, 1973). If so, the present condition of the Ross Ice Shelf is important for the future of the West Antarctic ice sheet. Using values for the velocities, strain-rates, and ice thicknesses measured during the Ross Ice Shelf Geophysical and Glaciological Survey (RIGGS) carried out between 1973 and 1978, Thomas and Bentley (1978) calculated the mass balance in three flow bands located in the grid north, central, and southern portions of the grid western half of the ice shelf (all subsequent directions in this paper refer to the grid system shown in Figure 1). Their calculations indicated that the ice in the northernmost flow band, which has come from Ice Streams "A" and "B", is thickening at a rate of $0.34 \pm 0.15 \mathrm{~m}$ of ice per year. Thomas and Bentley attributed the thickening rate in that sector of the ice shelf to the buttressing or blocking effect of Crary Ice Rise on the ice up-stream of it.

Further analysis of the radar data collected on the ice shelf, particularly during the 1974-75 NSF/ SPRI/TUD radio-echo sounding flights (directed by D.J. Drewry of the Scott Polar Research Institute), has since revealed an unexpected level of complexity in ice-shelf dynamics. A likely explanation for some intricate ice thickness and ice-flow patterns is the presence of several, previously unrecognized regions of grounded ice, one of which lies within Thomas and Bentley's northern flow band (Jezek and Bentley, 1983).

*Geophysical and Polar Research Center Contribution No. 408.

† Present address: U.S. Army Cold Regions Research and Engineering Laboratory,

Hanover, New Hampshire 03755, U.S.A. conclure à un épaississement à l'aide de la bande d'écoulement originale de Thomas et Bentley. C'est pourquoi une nouvelle bande d'écoulement, située plus à l'est que celle de Thomas et Bentley et non influencée par quelque zone de glace reposant sur le sol a été choisie. Le bilan de masse de cette bande d'écoulement n'est pas significativement diffërent de zéro; une différence de vitesse entre l'épaississement et l'accrétion à la base dépassant environ $0,2 \mathrm{~m} \mathrm{a}^{-1}$ n'est pas vraisemblable.

Zusammeneassung. Eine neue Betrachtung zur Massenbilanz eines Teiles des Ross Ice Shelf, Antarktika. Die Feststellung eines kleinen Gebietes aufsitzenden Eises im Nordwestsektor des Ross Ice Shelf zwang zu einer Neubewertung der Massenbilanzberechnungen von Thomas und Bentley (1978). Die genannten Autoren schlossen, dass sich das Ross Ice Shelf oberhalb des Crary Ice Rise verdickt, aber sie berücksichtigen dabei nicht die Einwirkungen des ihnen unbekannten aufsitzenden Eises nahe dem Einlass zu ihrem Volumenelement auf das Geschwindigkeitsfeld. Vernünftige Abschätzungen des Grades der Geschwindigkeitsabnahme gerade oberhalb des aufsitzenden Eises ergaben, dass es nicht mehr möglich ist, aus dem ursprünglichen Fliess-Streifen von Thomas und Bentley auf eine Dickenzunahme des ScheIfeises zu schliessen. Es wurde deshalb ein neuer Fliess-Streifen weiter östlich gewählt, der durch kein nahegelegenes Gebiet aüfsitzenden Eises beeinflusst wird. Die Massenbilanz in diesem Fliess-Streifen ergab sich unmessbar wenig verschieden von Null; eine Differenz zwischen der Verdickung und der Menge anfrierenden Eises an der Unterseite von mehr als etwa $0,2 \mathrm{~m}$ pro Jahr ist unwahrscheinlich.

Since grounding of the ice will surely perturb the velocity field, we have re-interpreted the strainrate, velocity, and ice thickness data and find that there is no longer statistically significant evidence for an imbalance in the flow band.

\section{OBSERVATIONS AND INTERPRETATIONS}

Jezek and Bentley (1983) concluded that there are several areas of grounded ice in the western Ross Ice Shelf (Fig. 1); they reached these conclusions on the basis of observations of a locally thin water layer, the positions of ice thickness maxima and minima, and the presence of large bottom crevasses (believed to form down-stream of grounded ice. The existence of such an area of grounded ice in the north-western corner of the ice shelf ("A" in Fig. 2) is supported both by the pattern of flow lines in the area (U.S. Geological Survey, 1972; also U.S.G.S. file photographs used in making that map), and by the icethickness gradients (Fig. 3, re-interpreted from the data used by Bentley and others (1979)). The strainrates measured at F6 (Thomas and others, in press) show that the velocity gradient has a pronounced south-westerly component, suggesting that the ice there is being deflected around the grounded ice. A less pronounced but still noticeable south-westerly component of velocity gradient at F7 suggests that there the ice is filling in behind the grounding zone. Both measurements are consistent with the presence of grounded ice between the two sites.

Figure 2 shows the velocity field in the vicinity of the flow band as interpreted by Thomas and Bentley (1978). We would expect the presence of grounded ice to reduce the ice velocity across part of the input 


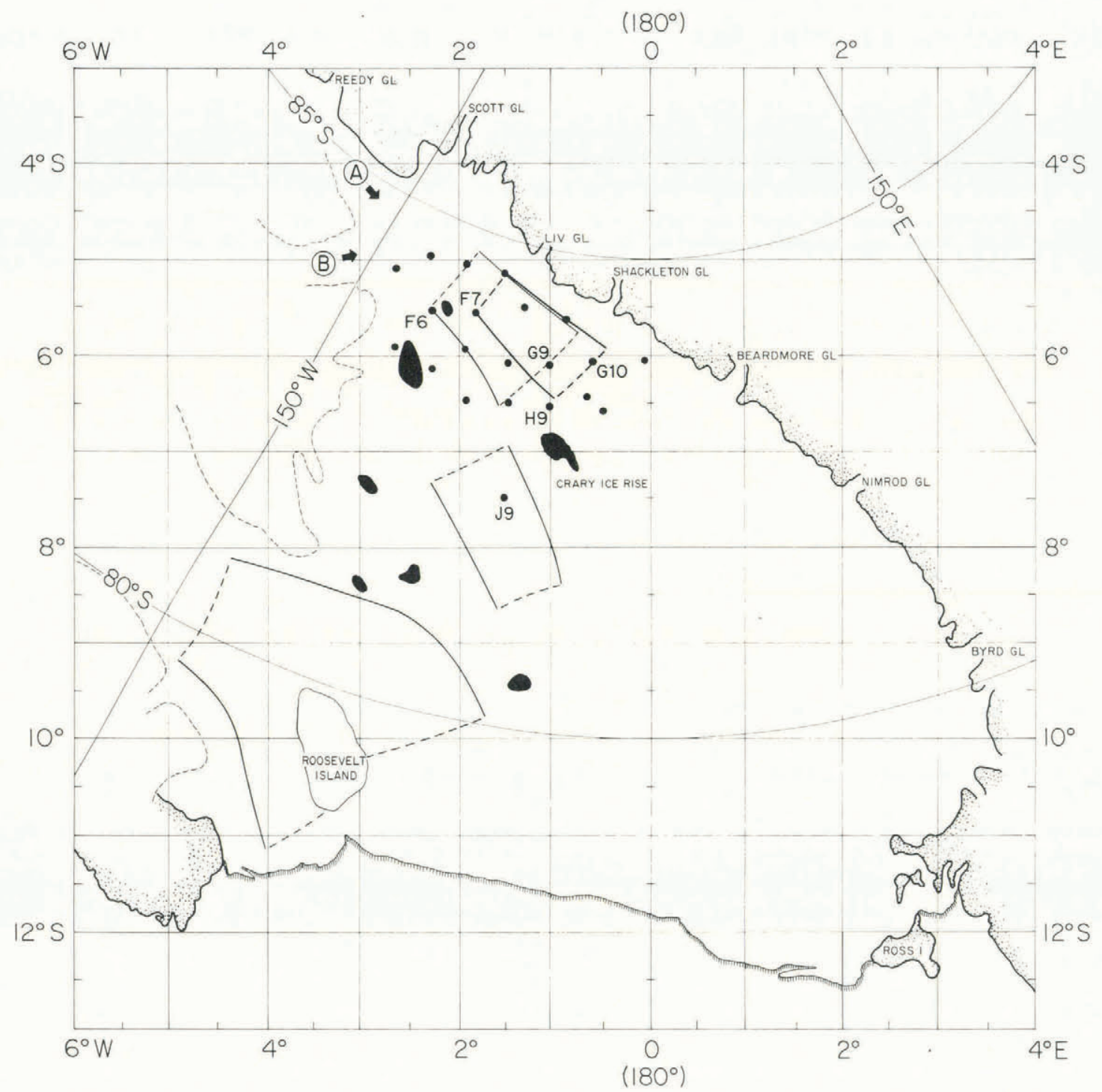

Fig. 1. Flow bands used to compute mass balance. The thinner lines denote Thomas and Bentley's (1978) three bands; the heavier lines outline the new flow band chosen so as to not be affected by any nearby areas of grounded ice (blackened areas of irregular shape). Black dots are RIGGS stations (shown only in the grid north west corner of the ice shelf); those referred to in the text are identified. Grounded ice area "A" is the one between RIGGS stations FG and F7. Ice streams $A$ and $B$ are marked by the circled letters in the grid northwest corner of the map. Grid coordinates are shown around the margin of the map - in this cartesian coordinate system $0^{\circ}$ grid longitude lies along the Greenwich and $180^{\circ}$ meridians with grid north towards Greenwich, and the grid equator passes through the geographic south pole.

gate of the flow band. Since we have insufficient data to define the flow quantitatively, we have limited ourselves to some semi-quantitative estimates of the effect of grounded ice area "A" on flow band abcd. (The velocity at F6 was not measured - the value presented by Thomas and others (in press) and shown in Figure 2 was linearly extrapolated from station F7 on the assumption of undisturbed ice shelf between the stations.) Figure 4 shows the ice thickness and velocity across the input gate of the volume element. (Ice thickness and velocity across the output gate are the same as those used by Thomas and Bentley, 1978). The three velocity curves are different interpretations of the velocity field: Model 1 (the upper curve) is the unperturbed velocity field used by Thomas and Bentley (1978). Model 2 (the middle curve) reduces the velocity up-stream of the ice rise by about one half, whereas Model 3 (the lower curve) represents the situation in which the ice is almost stagnant.

To avoid the disturbing effect of grounded areas, we have also examined a second flow band (efhg in Fig. 2). Although the velocity field in band efhy should be simpler and more accurately represented by the velocity vectors than in band abcd, this determination suffers from fewer ice thickness data across the input gate and from some uncertainty in the magnitude of the velocity across the output gate. Several interpretations of the ice thickness and velocity data across the gates are possible; we have made calculations with three different curves of ice thickness across the input gate (Fig. 5a), and three different curves of velocity across the output gate (Fig. 5b), representing those uncertainties. The problem with the input gate is in knowing the shape of the ice thickness trough, which clearly exists between e and 


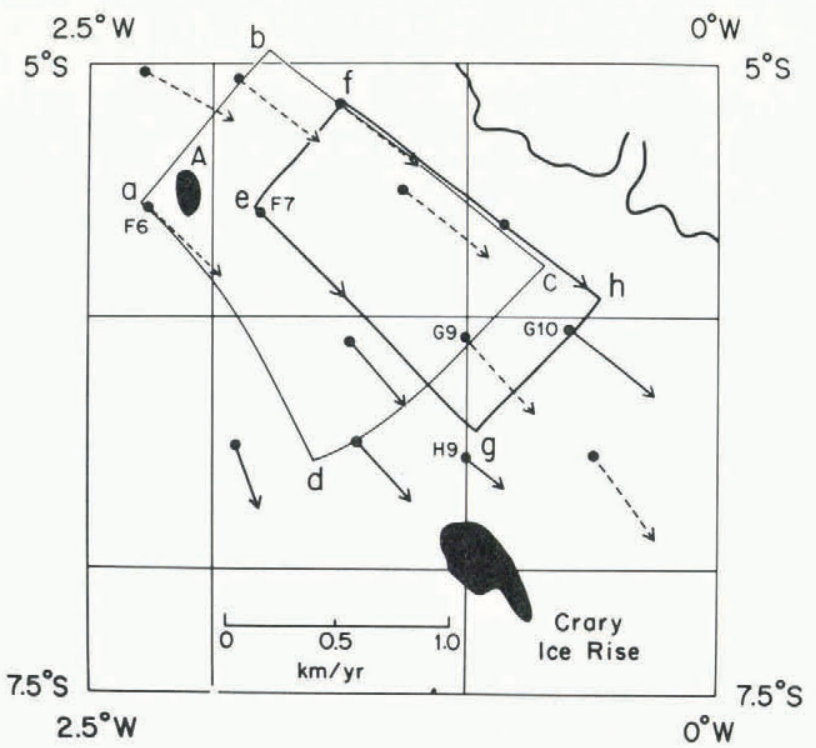

Fig. 2. Enlarged view of the grid north-west corner of the ice shelf showing Thomas and Bentley's (1978) flow band (abcd) and the new flow band (efhg). Direct measurements of velocity are represented by solid vectors; velocities extrapolated using strainrate data are shown by dashed vectors (velocities are from Thomas and others, in press). Crary Ice Rise and grounded ice area "A" are in solid black. RIGGS stations referred to in the text are identified.

$f$ but is poorly defined by the data (Fig. 3). For the output gate the principal uncertainty is in how rapidly the velocity diminishes south-westward toward station $\mathrm{H} 9$, where the effect of Crary Ice Rise is markedly apparent (Fig. 2).

In Figure 5, the middle curve of ice thickness, marked "best", corresponds to the contours in Fig. 3 . The "minimum" and "maximum" curves depict the thinnest and thickest ice that we consider to be reasonably consistent with the data. In Figure $4 b$, the "minimum" curve assumes a linear decrease in velocity from the position on the output gate directly downstream of station $\mathrm{G} 9$ to station $\mathrm{H9}$, the "maximum" curve assumes no velocity decrease at all within the output gate, and the "best" curve is a smoothlyvarying intermediate variation.

\section{CALCULATIONS}

The parameters used and the results of the calculations for the two flow bands are presented in

Table I. Comparison of the mass balance for flow band

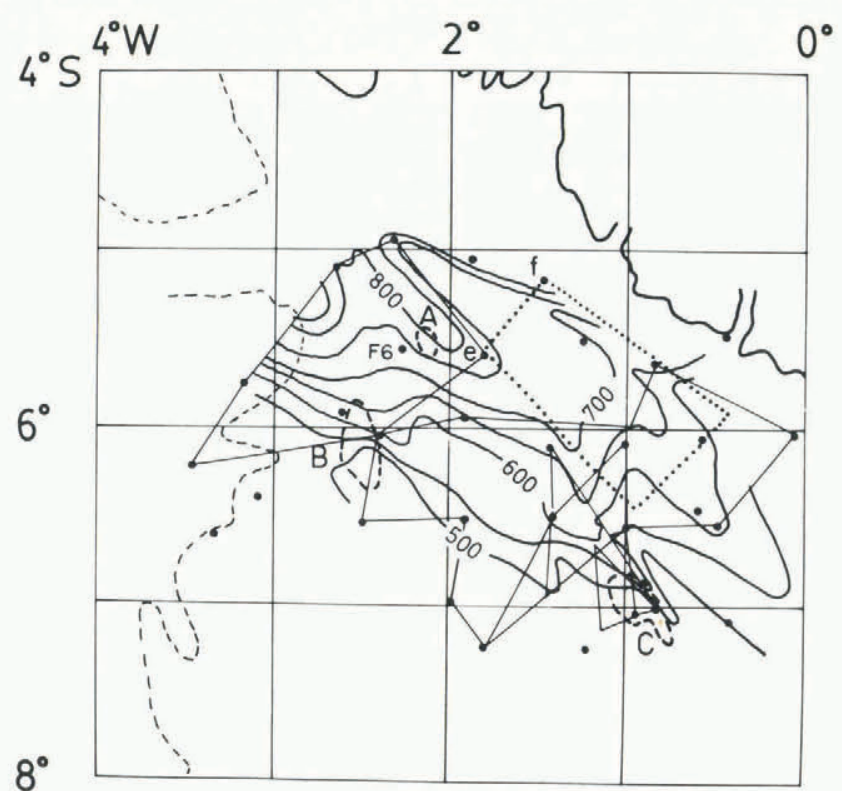

Fig. 3. Ice thickness contours. Thin line segments represent flight lines along which data were collected. Measurements were also made at the surface stations, indicated by black dots. Dashed areas are grounded ice areas " $A$ " and "B", and Crary Ice Rise $(" C$ "). The new flow band chosen for this analysis is outlined by the dotted lines.

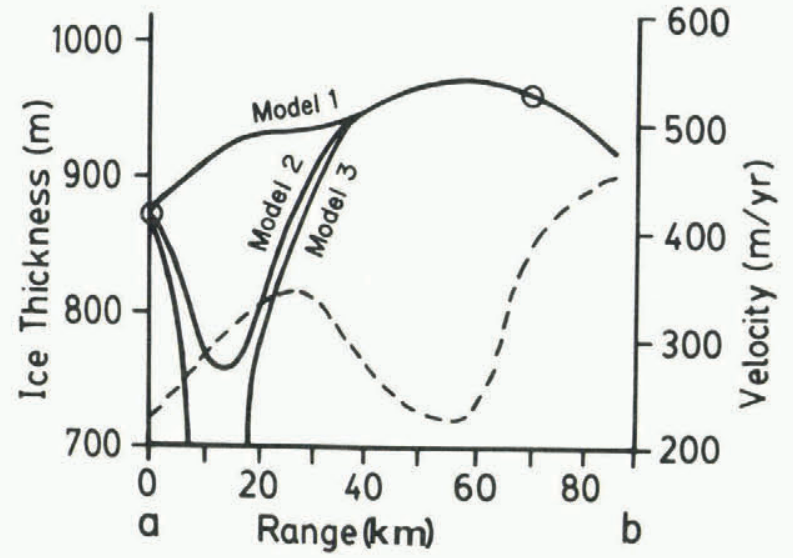

Fig. 4. Ice thickness (dashed line) and three models of the velocity (solid lines) along ab, the input gate to flow band abcd. The letters correspond to the end points of the input gate. The open circles show velocities calculated at the RIGGS stations that lie along $a b$.

TABLE I. PARAMETERS USED IN THE FLOW-BAND CALCULATIONS AND THE RESULTS OBTAINED Volume fluxes

\begin{tabular}{|c|c|c|c|c|c|c|c|}
\hline $\begin{array}{l}\text { Flow } \\
\text { band }\end{array}$ & $\begin{aligned} & \text { Area } S \\
= & 10^{3} \mathrm{~km}^{2}\end{aligned}$ & $\begin{array}{l}\text { Surface- } \\
\text { balance } \\
\text { rate } \\
=\mathrm{ma}^{-1}\end{array}$ & Model & $\begin{array}{l}\text { Input } \dot{Q}_{i} \\
=k m^{3} a^{-1}\end{array}$ & $\begin{array}{l}\text { Surface } \dot{Q}_{s} \\
=k m^{3} \quad a^{-1}\end{array}$ & $\begin{array}{l}\text { Output } \dot{Q}_{0} \\
=k m^{3} \quad a^{-1}\end{array}$ & $\begin{array}{l}\text { Rate of change } \\
\text { of ice thickness } \\
\quad=m a^{-1} \phi\end{array}$ \\
\hline abcd & $14.8 \pm 0.5^{*}$ & 0.13 & $\begin{array}{l}1 \\
2 \\
3\end{array}$ & $\begin{array}{l}34.0 \pm 0.7 \\
31.1 \pm 0.7 \\
27.8 \pm 0.7\end{array}$ & $\begin{array}{l}1.9 \pm 0.3 \\
1.9 \pm 0.3 \\
1.9 \pm 0.3\end{array}$ & $\begin{array}{l}30.8 \pm 2.0 \\
30.8 \pm 2.0 \\
30.8 \pm 2.0\end{array}$ & $\begin{array}{r}0.35 \pm 0.15 \\
0.15 \pm 0.15 \\
-0.07 \pm 0.15\end{array}$ \\
\hline efhg & 8.2 & 0.12 & $\begin{array}{l}\text { maximum } \\
\text { minimum } \\
\text { "best" }\end{array}$ & $\begin{array}{l}23 \\
20 \\
21.1\end{array}$ & $\begin{array}{l}1.0 \\
1.0 \\
1.0\end{array}$ & $\begin{array}{l}22 \\
21 \\
21.5\end{array}$ & $\begin{array}{r}+0.37 \\
-0.12 \\
0.07\end{array}$ \\
\hline
\end{tabular}

* Error limit does not take into account the likely deflection of flow line "ad" by the ice rise $\varnothing$ Assuming basal balance rate $Q_{b}=0$ 
abcd from Thomas and Bentley (1978) $\left(0.34 \pm 0.15 \mathrm{~m} \mathrm{a}^{-1}\right)$ with our corresponding result $\left(0.35 \pm 0.15 \mathrm{~m} \mathrm{a}^{-1}\right)$ indicates that the calculation was changed insignificantly by re-contouring the ice thickness. Models 2
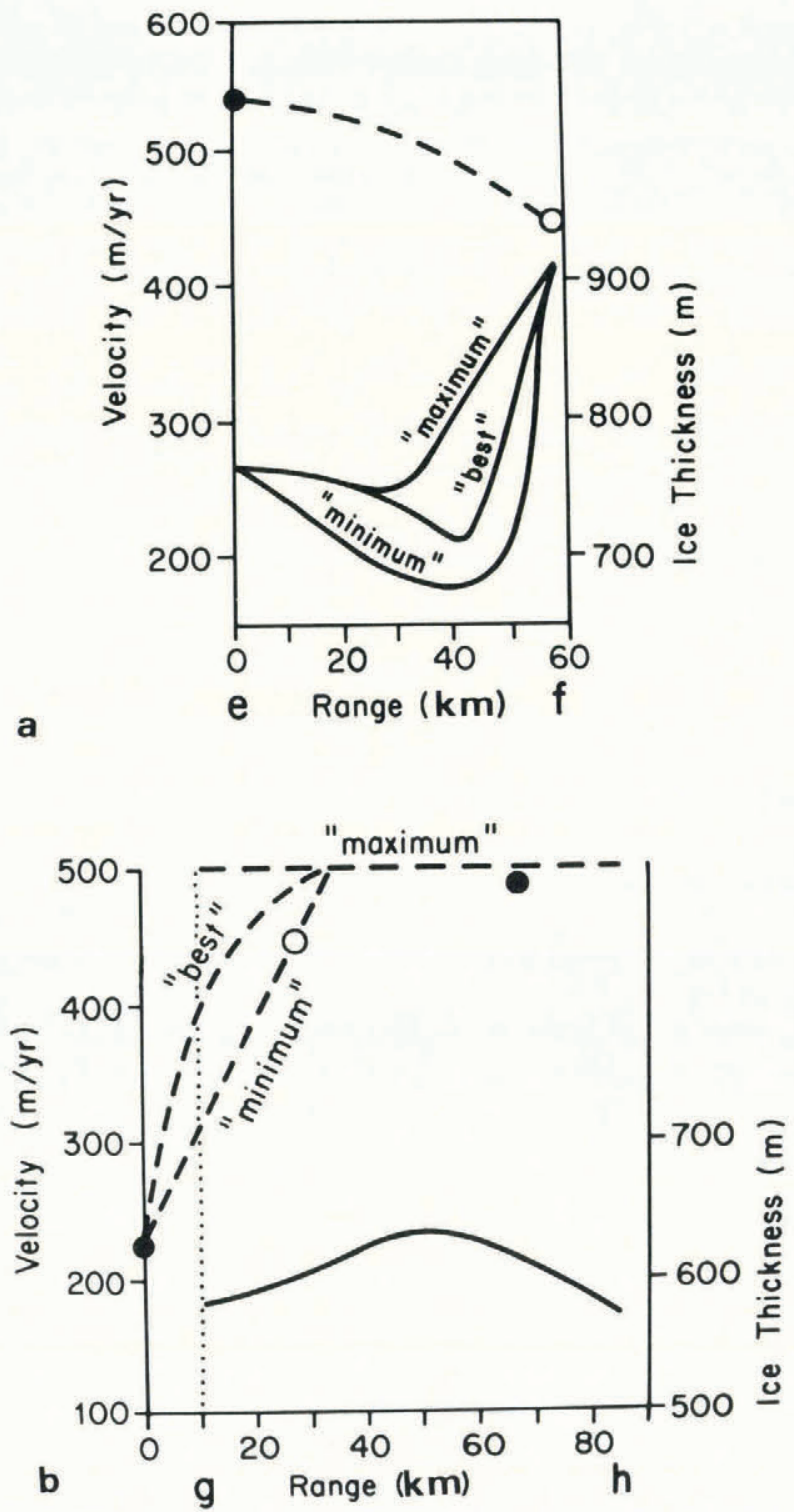

Fig. 5. Ice thicknesses (dashed lines) and velocities (solid lines) across the input ef and output gh gates of flow band efhy. "Maximum", "best", and "minimum" models are explained in the text. Solid circles indicate direct velocity measurements; open circles show velocities extrapolated from strain rate data. The "best" and "minimum" velocity curves across hg have been extended past the " $\mathrm{g}$ " end of the gate (vertical dotted line) to show how they are connected to the measured velocity at station $H 9$ (see Fig. 2). Velocity curves are extended beyond the grid southerm end of the flow band to a nearby station where absolute velocity was measured. and 3 for flow band abcd, which include estimates of the effect of the grounded ice, show that a positive value of $\dot{H}$ can no longer be demonstrated. This conclusion is strengthened by the likelihood that the deflection of ice around the area of grounded ice would cause a more strongly-divergent flow band than band "abcd" as drawn in Figure 2, thus causing an increase in the width of output gate $c d$ and a consequent increase in the outward mass flux.

For band efhg, the "maximum" and "minimum" values have been calculated by combining the "maximum" input with the "minimum" output, and the "minimum" input with the "maximum" output, respectively. The "best" value of $0.07 \mathrm{~m} \mathrm{a}^{-1}$ for $\dot{H}$ is clearly not significantly different from zero.

\section{CONCLUSIONS}

A previous conclusion of Thomas and Bentley (1978) that the ice shelf is thickening is negated if allowance is made for a grounded area in the north-west corner of the ice shelf. Instead, the mass balance evaluated using a reasonable selection of models for both Thomas and Bentley's (1978) original flow band and for a new flow band which excludes the grounded ice, is not significantly different from zero; this means that the ice shelf is not thinning or thickening by a measurable extent at present. Although one cannot infer that the ice shelf is necessarily in steady-state, the data do indicate that a growth or shrinkage of more than about $0.2 \mathrm{~m} \mathrm{a}^{-1}$ is unlikely. This is consistent with the findings of Thomas and Bentley (1978) for the other two flow bands in the western portion of the ice shelf.

\section{ACKNOWLEDGEMENTS}

This research was supported by National Science Foundation grants GV-36963, DPP76-01415, DPP79-20736, and DPP81-19989.

\section{REFERENCES}

Bentley, C.R., and others. 1979. Ice-thickness patterns and the dynamics of the Ross Ice Shelf, Antarctica, by C.R. Bentley, J.W. Clough, K.C. Jezek, and S. Shabtaie. Journal of Glaciology, Vol. 24, No. 90 , p. 287-94

Jezek, K.C., and Bentley, C.R. 1983. Field studies of bottom crevasses in the Ross Ice Shelf, Antarctica. Journal of Glaciology, Vol. 29, No. 101, p. 118-26. Thomas, R.H. 1973. The creep of ice shelves: theory. Journal of Glaciology, Vol. 12, No. 64, p. 45-53.

Thomas, R.H., and Bentley, C.R. 1978. The equilibrium state of the eastern half of the Ross Ice Shelf. Joumal of Glaciology, Vol. 20, No. 84, p. 509-18.

Thomas, R.H., and others. In press. Glaciological studies on the Ross Ice Shelf, Antarctica, 19731978 , by R.H. Thomas, D.R. MacAyeal, D.H. Eilers, and D.R. Gaylord. (In Hayes, D., and Bentley, C.R., ed. The Ross Ice Shelf: glaciology and geophysics. Washington, D.C., American Geophysical Union. (Antarctic Research Series, Vol. 40.))

U.S. Geological Survey. 1972. Map of the Ross Ice Shelf. Washington, D.C., U.S. Geological Survey and National Science Foundation. [Scale 1 : 2188800.$]$ 